\title{
7 \\ Future of Russian Coal Exports in the Asia-Pacific
}

\author{
Stephen Fortescue
}

Russia is a major coal producer and an up-and-coming supplier of coal to the Asia-Pacific region (APR). In 2017, Russia was the world's sixth-largest producer, with a 5.3 per cent share (Australia was fourth with 6.2 per cent), and third-largest exporter, with an 18 per cent share (Australia was first with 41.1 per cent). ${ }^{1}$ In 2018 , Russia exported around $120 \mathrm{mmt}$ to the APR. As a rough point of comparison, in the 12 months between 2016 and 2017, Australia exported $379 \mathrm{mmt}$, overwhelmingly to the APR. Russia has serious ambitions to strengthen its position in this region.

This chapter reviews progress in Russia's development of an APR-oriented coal export industry and evaluates prospects for further development. No attempt is made to describe or analyse demand issues. The focus is on the availability of coal and the capacity to get it to market. This chapter also asks whether an APR export strategy is commercially sustainable and what might be the cost to the Russian state of trying to make it so. While not systematically, Australia's coal export industry is used as a comparator.

1 'Coal of Russia and the World: Production, Consumption, Export, Import', Central Dispatch Office of the Fuel and Energy Complex, 27 September 2018, cdu.ru/tek_russia/issue/2018/7/499/. 
As noted in mid-2018 by Russian Minister for Energy Aleksandr Novak, the major targets set in the Program for the Development of the Coal Industry of Russia for the Period to 2030, approved in 2014 and referred to in what follows as the Program, ${ }^{2}$ had been or were set to be achieved well ahead of schedule. ${ }^{3}$ Table 7.1 shows the Program forecasts for 2020, 2025 and 2030 , with actual figures for 2018. It can be seen that output approached the 2025 target in 2018, that total exports exceeded it and that exports to the APR approached it.

Table 7.1: Forecasts in the Program for the Development of the Coal Industry of Russia for the Period to 2030, with outcome in 2018 (mmt)

\begin{tabular}{|l|c|c|c|c|}
\hline & $\mathbf{2 0 1 8}$ actual & $\mathbf{2 0 2 0}$ actual & $\mathbf{2 0 2 5}$ forecast & $\mathbf{2 0 3 0}$ forecast \\
\hline Output & 439.3 & 401.6 & 450 & 500 \\
\hline - Coking & 98.3 & 92.3 & 158 & 200 \\
\hline - Thermal & 341.0 & 309.3 & 292 & 300 \\
\hline Exports & 193.2 & 195.6 & 180 & 205 \\
\hline - Coking & 16.3 & 21.6 & 45 & 60 \\
\hline - Thermal & 176.9 & 174.0 & 135 & 145 \\
\hline Exports to APR & $120.8^{\star}$ & 120.8 & 95 & 120 \\
\hline
\end{tabular}

${ }^{*}$ Calculated from Table 7.3. There might be some exports from regions not included in that table.

Source: Programma razvitiia ugol'noi promyshlennosti Rossii na period do 2030 goda [Program for development of Russia's coal industry for the period to 2030], approved by government directive no. 1099-r, 21 June 2014, 9; Igor' Gennadievich Tarazanov, 'Itogi raboty ugol'noi promyshlennosti Rossii za ianvar'-dekabr' 2018 goda' [Results of the work of the coal industry in Russia for January-December 2018], Ugol' 3 (2019): 64-79, doi.org/ 10.18796/0041-5790-2019-3-64-79.

The stronger than predicted performance led Novak to undertake a revision of the Program, taking the end date out to 2035. In June 2020, the new Program was approved by the Russian government. ${ }^{4}$ At an August 2018 meeting, Novak reported that the ministry had arrived at new output forecasts, in consultation with coal companies, of $560 \mathrm{mmt}$ in 2025

2 Programma razvitiia ugol'noi promyshlennosti Rossii na period do 2030 goda [Program for development of Russia's coal industry for the period to 2030], approved by government directive no. 1099-r, 21 June 2014.

3 'Meeting of the Commission on the Development Strategy of the Fuel and Energy Complex and Environmental Safety', President of Russia, 27 August 2018, kremlin.ru/events/president/news/58382. $4 \quad$ Sergey Sukhankin, 'Coal Strategy 2035: Is Russia Preparing for the Last War?', Eurasia Daily Monitor 17, 109 (2020), jamestown.org/program/coal-strategy-2035-is-russia-preparing-for-the-lastwar/. 
(the Program had forecast 450) and $590 \mathrm{mmt}$ in 2030 (the Program had forecast 500). He estimated that exports to the APR in 2018 would be around $100 \mathrm{mmt}$ (Table 7.1 suggests higher), and that that figure could be doubled to $207 \mathrm{mmt}$ in 2025.5

Twelve months later, as the revised Program was being drawn up, Novak reported two forecasts for output by 2035: 550 or $670 \mathrm{mmt}$. He noted that coal companies were predicting $770 \mathrm{mmt}$, but that the ministry had decided to be more cautious. ${ }^{6}$ The newspaper Kommersant claimed to have seen more detailed figures, which forecast exports at 322-92 mmt, of which 214-20 mmt would be exported to the APR. ${ }^{7}$

There is clearly a struggle underway between optimistic coal producers and more cautious government planners, the suspicion being that the former are making ambit claims in order to maximise government commitment to infrastructure provision, on which more below.

Table 7.2: Output by selected regions as forecast in the Program for the Development of the Coal Industry of Russia for the Period to 2030, with outcomes in 2013 and 2018 (mmt)

\begin{tabular}{|l|c|c|c|c|}
\hline & $\mathbf{2 0 1 3}$ actual & $\mathbf{2 0 1 8}$ actual & $\mathbf{2 0 2 0}$ actual & 2030 forecast \\
\hline Kuzbass & 203.6 & 255.3 & 232.1 & 178 \\
\hline East Siberia & 88.6 & 79.4 & 74.6 & 162 \\
\hline Russian Far East & 33.1 & 74.1 & 78.9 & 122 \\
\hline
\end{tabular}

Source: Programma razvitiia ugol'noi promyshlennosti Rossii na period do 2030 goda [Program for development of Russia's coal industry for the period to 2030], approved by government directive no. 1099-r, 21 June 2014, 16; Igor' Gennadievich Tarazanov, 'Itogi raboty ugol'noi promyshlennosti Rossii za ianvar'-dekabr' 2018 goda' [Results of the work of the coal industry in Russia for January-December 2018], Ugol' 3 (2019): 64-79, doi.org/ 10.18796/0041-5790-2019-3-64-79.

5 'Meeting of the Commission on the Development Strategy of the Fuel and Energy Complex and Environmental Safety'.

6 'Meeting with Leaders of Coal Mining Regions'.

7 Natal'ia Skorlygina and Evgenii Zainullin, 'Vse budet narubis' [All will be chopped], Kommersant, 23 August 2019. 
Table 7.3: Exports to the Asia-Pacific from selected regions as forecast in the Program for the Development of the Coal Industry of Russia for the Period to 2030, with outcomes in 2013 and 2018 (mmt)

\begin{tabular}{|l|c|c|c|}
\hline & $\mathbf{2 0 1 3}$ actual & $\mathbf{2 0 1 8}$ actual & $\mathbf{2 0 3 0}$ forecast \\
\hline Kuzbass & 35.0 & $79.06^{\star}$ & 27.0 \\
\hline East Siberia & 12.7 & $12.50^{\star \star}$ & 20.0 \\
\hline Russian Far East & 10.9 & $29.24^{\star \star}$ & 46.0 \\
\hline
\end{tabular}

*Calculated from Natal'ia Skorlygina and Anatolii Dzhumailo, 'Velikii ugol'nyi put' [The great coal route], Kommersant, 26 July 2018.

**These figures are for total exports from the region. It is assumed that all exports go to the APR. See, Igor' Gennadievich Tarazanov, 'Itogi raboty ugol'noi promyshlennosti Rossii za ianvar'-dekabr' 2018 goda' [Results of the work of the coal industry in Russia for JanuaryDecember 2018], Ugol' 3 (2019): 64-79, doi.org/10.18796/0041-5790-2019-3-64-79.

Source: Programma razvitiia ugol'noi promyshlennosti Rossii na period do 2030 goda [Program for development of Russia's coal industry for the period to 2030], approved by government directive no. 1099-r, 21 June 2014, 17.

As is evident from Tables 7.2 and 7.3, the forecasts set in 2014 saw a decline in Kuzbass output and exports to the APR, to be made up for by new capacity in the Russian Far East (RFE) and East Siberia. So far, this has not happened-Kuzbass has massively exceeded forecasts already and the RFE and East Siberia could well struggle to meet the targets. We have no figures on what the Russian Ministry of Energy sees as the contribution of different regions into the future. But figures that Kommersant claimed in July 2018 to have been agreed between the Kemerovo regional administration (Kemerovo being the core administrative region of the Kuzbass) and local coal companies predict exports of $126.5 \mathrm{mmt}$ from the region to the APR in 2025 (from output of $394.6 \mathrm{mmt}$ ). ${ }^{8}$ The Program did not provide forecasts for exports by region in 2025, but the new figure is considerably above the Program's forecast of $27 \mathrm{mmt}$ from Kuzbass in 2030. If it were to be achieved, other regions would have to contribute $80.5 \mathrm{mmt}$ to meet Novak's prediction of $207 \mathrm{mmt}$ of APR exports by 2025. The Program had an $8 \mathrm{mmt}$ contribution from neighbouring Khakasia and $19 \mathrm{mmt}$ from 'others', presumably from Arctic deposits to be briefly described below, by $2030 .{ }^{9}$ The RFE and East Siberia were slated

8 Natal'ia Skorlygina and Anatolii Dzhumailo, 'Velikii ugol'nyi put' [The great coal route], Kommersant, 26 July 2018.

9 Export forecasts are not available, but Khakasia's output in 2030 is predicted to be $46 \mathrm{mmt}$. See, Dmitrii Lysenko, Dmitrii Akatov and Natal'ia Skorykh, 'Faktory i tendentsii razvitiia ugeldobyvaiushchei promyshlennosti Respubliki Khakasiia' [Factors and trends in the development of the coal mining industry in the Republic of Khakassia], Ugol'5 (2019): 28-30, doi.org/10.18796/ 0041-5790-2019-5-28-30. 
to provide $66 \mathrm{mmt}$, making a non-Kuzbass total of $93 \mathrm{mmt}$. Thus, if the recent Kuzbass predictions have any basis in reality, the share of APR exports of other regions is expected to be less than were forecast in 2014. If current trends are maintained, East Siberia and RFE might reach their targets, but further analysis is undertaken below to determine whether those trends can indeed be maintained, and, in particular, sufficiently so to make up the gap if Kuzbass fails to perform as forecast.

There are two implications of the unforeseen continued dominance of Kuzbass coal. First, that the expected increase in the share of coking coal forecast in 2014 will not materialise, given the predominance of thermal coal in Kuzbass output; and, second, that coal being exported to the APR has to be shipped further by rail than would be the case if more coal were coming from East Siberia and the RFE. These are matters to which we will return. But first some consideration must be given to the sustainability of the Kuzbass expansion, and the reasons for, and chances of, reversal of relatively poor East Siberian and RFE performance.

\section{Kuzbass}

Kuzbass is a large topic that cannot receive the attention due in the space available here. Kuzbass coal is like West Siberian oil: despite constant predictions of the peak having been reached, output continues to increase. One hesitates to bet against the positive trend continuing. Nevertheless, not everyone is optimistic. Kopytov and Shaklein express scepticism about the region's reserves data, which are based on exploration done in the Soviet period, as well as doubts about the sustainability, on social and environmental grounds, of the open-cut mining on which big increases in output depend. ${ }^{10}$ In what admittedly sounds like lobbying for underground mining (one author being a professor in the Department of Underground Structures and Mines at Kuzbass State Technical University), they call for the development of new technology to enable more intensive underground recovery. Plakitkina and Plakitkin also see Kuzbass as close

10 A. I. Kopytov and S. V. Shaklein, 'Napravlenie sovershenstvovaniia strategii razvitiia ugol'noi otrasli Kuzbassa' [Approach to improving the Kuzbass's coal industry's development strategy], Ugol' 5 (2018): 80-86. 
to the limit on both production and environmental dimensions (while also noting the poor performance of East Siberia). ${ }^{11}$ As a consequence, their scenarios for future coal output show a decline to 2025 .

There have long been strong social and environmental pressures on Kuzbass coal, with mine explosions leading to a program to close dangerous pits, and atmospheric pollution leading to calls_including from Aman Tuleev, the long-time governor of Kemerovo region-for a moratorium on granting new mining licences. ${ }^{12}$ Tuleev, however, was replaced in April 2018 by Sergei Tsivilev, a mine owner from outside the region, while scepticism was warranted given the new owner, limited mining activity stemmed more from production issues in the Kuzbass coal zone.

\section{Russian Far East}

The situation in the RFE is examined by region.

\section{Sakhalin}

Table 7.4 shows significant increases in output and exports from a low base since 2012. Over the period, an increasing share of output has been exported, to virtually 100 per cent, a consequence of the gasification of the domestic regional market. In 2017, the main destinations for Sakhalin coal were South Korea $(3.432 \mathrm{mmt})$, China $(1.979 \mathrm{mmt})$ and Philippines (807 tmt). ${ }^{13}$ (Table 7.5 shows Russia's export markets more generally.) Beyond a vague claim in 2017 by then governor Kozhemiako that exports could reach $20 \mathrm{mmt} / \mathrm{y}$ sometime in the future, no recent estimates of future regional output or exports have been found. ${ }^{14}$

11 L. S. Plakitkina and Iu. A. Plakitkin, 'Novye tsenarii razvitiia ekonomiki Rossii: aktualizirovannye prognozy razvitiia dobychi uglia v period do 2025 goda' [New scenarios for the development of the Russian economy: Updated forecasts for the development of coal mining in the period up to 2025], Ugol' (2018): 66-71, doi.org/10.18796/0041-5790-2018-5-66-71.

12 Igor' Lavrenkov, Tat'iana Kosacheva and Anatolii Dzhumailo, 'Kuzbass prikroet dostup v nedra' [Kuzbass will cover access to raw materials], Kommersant, 18 December 2017.

13 'Coal Industry', Governor and Government of the Sakhalin Region, accessed 24 August 2020, sakhalin.gov.ru/index.php?id=162.

14 'The Governor of Sakhalin Expects an Increase in Investment in the Coal Industry', Union State, 9 April 2017, ria.ru/20170904/1501704458.html. 
Table 7.4: Output and exports from Sakhalin (mmt)

\begin{tabular}{|l|c|c|c|c|}
\hline & $\mathbf{2 0 1 2}$ & $\mathbf{2 0 1 6}$ & $\mathbf{2 0 1 7}$ & $\mathbf{2 0 1 8}$ \\
\hline Output & 4.1 & 6.97 & 7.65 & 10.8 \\
\hline Exports & 1.92 & 4.65 & 7.53 & 10 \\
\hline
\end{tabular}

Source: 'Coal Industry', Governor and Government of the Sakhalin Region, accessed 24 August 2020, sakhalin.gov.ru/index.php?id=162; 'Vneshnetorgovyy oborot Sakhalinskoy oblasti v 2012 godu sostavil 17,8 mlrd' [The foreign trade turnover of the Sakhalin region in 2012 amounted to $\$ 17.8$ billion], Sakhalin.Biznes, 1 April 2013, sakhalin.biz/en/news/ finance/82458.

Table 7.5: Russian coal export destinations, 2018, top five worldwide and other Asian destinations (mmt)

\begin{tabular}{|l|l|c|c|}
\hline Rank & Destination & Deliveries 2018 & \% change on 2017 \\
\hline 1 & South Korea & 29.182 & +11.7 \\
\hline 2 & China & 27.591 & +7.6 \\
\hline 3 & Japan & 18.277 & +3.9 \\
\hline 4 & Ukraine & 14.206 & +53.2 \\
\hline 5 & Germany & 13.835 & +42.1 \\
\hline 9 & Taiwan & 9.308 & +6.1 \\
\hline 11 & India & 4.492 & +24.8 \\
\hline 15 & Malaysia & 3.134 & +2.3 \\
\hline 17 & Vietnam & 2.649 & +15.3 \\
\hline 26 & Hong Kong & 1.161 & -2.3 \\
\hline 27 & Philippines & 1.063 & +8.9 \\
\hline 28 & Thailand & 0.970 & -30.9 \\
\hline
\end{tabular}

Source: Igor' Gennadievich Tarazanov, 'Itogi raboty ugol'noi promyshlennosti Rossii za ianvar'-dekabr' 2018 goda' [Results of the work of the coal industry in Russia for JanuaryDecember 2018], Ugol' 3 (2019): 76, doi.org/10.18796/0041-5790-2019-3-64-79.

The dominant producer is VGK (Vostochnaia gornorudnaia kompaniia), which, according to some sources, has squeezed out other producers through its influence over the licensing process. ${ }^{15}$ It operates the Solntsevskii and Boshniakovskii open-cut mines. ${ }^{16}$ Solntsevskii produced $7.51 \mathrm{mmt}$ in 2018 of which it exported $7.47 \mathrm{mmt}$, an increase of

15 'Misevra Can Get More Boshnyakovsky Coal', Business Newspaper, 5 December 2016, biznesgazeta.ru/?id=location.view\&obj=d1b0855b88ac30e0c6855d800550691e.

16 VGK's ownership of the latter is claimed in 'Misevra Can Get More Boshnyakovsky Coal', but confirmation has not been found. 
55.1 per cent on 2017. ${ }^{17}$ Boshniakovskii produced 901,000 metric tons in 2017 and 880,300 metric tons in 2018. Export figures have not been found. Claimed maximum capacity of the mine is $1 \mathrm{mmt} / \mathrm{y}$ for 10 years. ${ }^{18}$ VGK wants to reach $10-12 \mathrm{mmt} / \mathrm{y}$ peak capacity for the two mines combined. ${ }^{19}$

The only other Sakhalin miner of any note is Gorniak-1, based in Nevel'sk. One source claims that it exported nearly 800,000 metric tons (of $1.367 \mathrm{mmt}$ dug) in 2017, up significantly from 138,000 metric tons in 2015 and 293,000 metric tons in 2016. Peak output is put at $3 \mathrm{mmt}^{20}$ Another source states Gorniak-1 exported $1.36 \mathrm{mmt}$ in 2018, down 1.7 per cent on the 2017 figure. $^{21}$

None of Sakhalin's ports are deepwater, meaning that coal is loaded by lighter into carriers standing offshore, seriously increasing shipping costs. There has been talk of building a $10 \mathrm{mmt} / \mathrm{y}$ deepwater terminal at the current port of Shakhtersk, as well as a deepwater port in the south of the island, at Il'inskoe. ${ }^{22}$ The fate of the latter is tied to the recurring grand scheme of building a bridge to Sakhalin from the mainland. As will be discussed further below, the bridge would mainly carry coal from the mainland through Sakhalin and on to APR markets. The new port would at the same time improve logistics for Sakhalin miners, although in the end their output potential and ambitions are so limited that improved logistics will not turn them into major exporters.

\section{Khabarovsk}

The only producer in the Khabarovsk region is Urgalugol', owned by the Kuzbass giant SUEK. As Table 7.6 shows, the company steadily increased output until 2017, with a decline in 2018. Throughout, it has consistently

17 Igor' Gennadievich Tarazanov, 'Itogi raboty ugol'noi promyshlennosti Rossii za ianvar'-dekabr' 2018 goda' [Results of the work of the coal industry in Russia for January-December 2018], Ugol' 3 (2019): 64-79, 76, doi.org/10.18796/0041-5790-2019-3-64-79.

18 'Boshnyakovsky Coal Mine was the First to Receive the Status of a Regional Investment Project', Sakhalin.Info, 22 June 2017, sakhalin.info/news/134516.

19 Anatolii Dzhumailo, 'VGK aktiviziruet ugol' [VGK is activating coal], Kommersant, 3 September 2015.

20 Natalia Golubkova, 'General Director of LLC “Gornyak-1”: Russian Railways Policy Does Not Meet the Requirements of the State and Business', Sakhalin.Info, 13 April 2008, sakhalin.info/news/ 150205 .

21 Tarazanov, 'Itogi raboty ugol'noi promyshlennosti', 76.

22 Dzhumailo, 'VGK aktiviziruet ugol'. 
been unable to meet targets. The difficulty appears to be exhaustion of existing deposits and delays in scaling up the new Pravoberezhnaia open-cut mine (the company mines both open-cut and underground: the 2015 output was divided into $2.43 \mathrm{mmt}$ open-cut and $3.167 \mathrm{mmt}$ underground). The new mine, which opened in November 2017, is designed to reach a maximum capacity of $3 \mathrm{mmt} / \mathrm{y}$ in 2021 . $^{23}$ The company's coal is of poor quality and requires enrichment in a plant that cost 17 billion. ${ }^{24}$ The company has a major market in the domestic power generation sector; in 2013, it exported 2.937 of 4.639 mmt of output. ${ }^{25}$ More recent export data have not been found, but predicted peak exports are put at $15 \mathrm{mmt} / \mathrm{y}^{26}$ That would require a very substantial increase in output - the company CEO sees $10 \mathrm{mmt} / \mathrm{y}$ as the output target for the near future. ${ }^{27}$

Table 7.6: Output of Urgalugol', forecast and actual (mmt)

\begin{tabular}{|l|c|c|c|c|c|c|c|c|}
\hline & $\mathbf{2 0 0 4}$ & $\mathbf{2 0 1 0}$ & $\mathbf{2 0 1 3}$ & $\mathbf{2 0 1 5}$ & $\mathbf{2 0 1 6}$ & $\mathbf{2 0 1 7}$ & $\mathbf{2 0 1 8}$ & $\mathbf{2 0 1 9}$ \\
\hline Forecast & N/A & 5.6 & N/A & N/A & 9.1 & N/A & 8 & 8.1 \\
\hline Actual & 2.6 & 2.7 & 4.64 & 5.6 & 6.6 & 6.5 & 6.14 & N/A \\
\hline
\end{tabular}

Source: 'Urgalugol Will Work for the Export of Electricity', Kommersant, 22 March 2007, kommersant.ru/doc/752351; Stephen Fortescue, 'Russia's Economic Prospects in the Asia-Pacific Region', Journal of Eurasian Studies 7, 1 (2016): 49-59, 55, doi.org/10.1016/ j.euras.2015.10.005; 'On Supplementing the List of Investment Projects Planned for Implementation in the Far East', Russian Government, 5 September 2017, government. ru/docs/29123/; V. B. Artem'ev, 'SUEK-itogi 2017 goda' [SUEK-results of 2017], Ugol' 3 (2018): 4-13, 13, doi.org/10.18796/0041-5790-2018-3-4-13; Igor' Gennadievich Tarazanov, 'Itogi raboty ugol'noi promyshlennosti Rossii za ianvar'-dekabr' 2018 goda' [Results of the work of the coal industry in Russia for January-December 2018], Ugol' 3 (2019): 66, doi.org/10.18796/0041-5790-2019-3-64-79.

23 V. B. Artem'ev, 'SUEK—itogi 2017 goda' [SUEK—results of 2017], Ugol' 3 (2018): 4-13, 11, doi.org/10.18796/0041-5790-2018-3-4-13.

24 Irina Sergeeva, 'Prostaia arifmetika AO "Uralugol”' [Simple arithmetic of JSC 'Urgalugol'], DV Kapital, 18 December 2018, dvkapital.ru/companies/khabarovskij-kraj_18.12.2018_13748_ prostaja-arifmetika-ao-urgalugol.html.

25 Stephen Fortescue, 'Russia's Economic Prospects in the Asia-Pacific Region', Journal of Eurasian Studies 7, 1 (2016): 49-59, 55, doi.org/10.1016/j.euras.2015.10.005.

26 "The Working Settlement of Chegdomyn Is the "Heart" of the Coal Mining Industry of the Khabarovsk Territory', Ministry of Economic Development of the Khabarovsk Territory, 25 February 2018, minec.khabkrai.ru/events/Novosti/2975.

27 Sergeeva, 'Prostaia arifmetika AO "Uralugol". 


\section{Primor'e and Amur}

The major coal companies in the Primor'e and Amur regions, Primorskugol' and Amurugol', traditionally produced almost exclusively for the domestic power generation market. The former produced $3.6 \mathrm{mmt}$ and the latter $3.53 \mathrm{mmt}$ in $2018 .^{28}$ Primorskugol' began exporting in 2016 and, in 2017, exported 467,800 metric tons. ${ }^{29}$ No export data on Amurugol' are available. A new field in the Amur region, at SugodinskoOgodzhina, started production in 2020 with an output of $10 \mathrm{mmt} / \mathrm{y}$ to be reached by 2022, and a maximum capacity of $20 \mathrm{mt} / \mathrm{y} .{ }^{30}$ The project is owned by Dmitrii Bosov, of whom we will hear more below. There are occasional references to a Chinese-connected venture, Primor'e-Suchanugol', with plans to revive the closed mine at Partizansk (expected annual output of 500,000 metric tons, with reserves of $15 \mathrm{mmt}) .{ }^{31}$

\section{Northern RFE}

There is talk of greenfield projects in Magadan and Kamchatka. ${ }^{32}$ But it is in even more remote Chukotka that actual mining activity can be found. The Beringovskii mine is on the Pacific coast of Chukotka; its core shareholder is the Australian Tigers Realm Coal Company, with a 14.4 per cent investment by the Russian Direct Investment Fund. It is a coking coalmine, unlike the thermal coalmines further south. The first coal was mined in January 2017, with 217,400 metric tons dug that year. From January to October 2018, 433,150 metric tons were dug. Early shipments were to domestic ports along the coast, with the first export shipment being 100,000 metric tons to China. In 2017-18, 259,000 metric tons

28 Tarazanov, 'Itogi raboty ugol'noi promyshlennosti', 66.

29 Kompaniia, 'Primorskugol' v iubileinyi god professional'nogo prazdnika Den' shakhtera: 70 let radi sveta i tepla!' [Primorskugol' in the jubilee year of the industry holiday miner's day: 70 years producing light and warmth!], Ugol', 3 (2018): 21-26, 22.

30 'Sugodinsko-Ogodzhinskoe Field: The Largest Coal Deposit in the Far East Region', Vostok Coal, accessed 1 April 2021, vostokcoal.ru/assets/sugodinsko-ogodginskoe-mestorozhdenie/.

31 'A Free Port Resident Will Create a Coal Cluster in Primorye with Investments of 4 Billion Rubles', TASS, accessed 24 August 2020, tass.ru/vef-2017/articles/4544606.

32 'CJSC North-Eastern Coal Company', EMCO, accessed 24 August 2020, eastmining.ru/pred priiatiia/severo-vostochnaia-ugol-naia-kompaniia/; Nicholas Trickett, 'Is Russia's Asia Outreach Bearing Fruit?', Diplomat, 6 April 2017, thediplomat.com/2017/04/is-russias-asia-outreach-bearing-fruit/. 
were exported. ${ }^{33}$ Port facilities are extremely primitive, ${ }^{34}$ but there are plans for modernisation to take capacity to an eventual $10 \mathrm{mmt} / \mathrm{y} .{ }^{35}$ Even when the port is modernised, it will be closed by ice eight months a year with icebreakers required for some of the summer period. ${ }^{36}$

While RFE coal has shown growth in recent years, forecasts of future growth and exports, particularly at the level of individual producers, are modest - something like $50 \mathrm{mmt} / \mathrm{y}$ at peak capacity. Further gasification might allow greater exports of Primorskugol' and Amurskugol' output, but that would not be enough to make RFE a significant contributor to APR exports. ${ }^{37}$

\section{East Siberia}

The figures for East Siberia are also modest. There are established producers: Vostsibugol', owned by Oleg Deripaska's En+, and Yakutugol', owned by the steelmaker Mechel. The former produces thermal coal primarily for the power stations of Deripaska's Irkutsk Energy Company. However it also exports. In 2017, it met its export target of $1.1 \mathrm{mmt}$ and was looking for $2 \mathrm{mmt}$ in 2018. ${ }^{38}$ Yakutugol' supplies Mechel's steel plants, but also exports coking coal from the Neriungri area in south Yakutia. The mines are not far from a rail line with a direct link to the BaikalAmur Mainline (BAM). However, the deposits are depleted, as can be

33 A. Ignat'eva and O. Bakhtina, 'Ugol' Chukotki! Dlia morskogo porta Beringovskii razrabotaiut predlozhneiia po sozdaniiu infrastruktury' [Chukotka coal! Proposals for the creation of infrastructure will be developed for the seaport of Beringovsky], Neftegaz.ru, 30 October 2018, neftegaz.ru/news/ transport-and-storage/197408-ugol-chukotki-dlya-morskogo-porta-beringovskiy-razrabotayutpredlozheniya-po-sozdaniyu-infrastruktur/.

34 'Beringovsky Commercial Sea Port', Basov-Chukotka, accessed 24 August 2020, basov-chukotka. livejournal.com/384644.html.

35 'On Major Projects for the Development of Transport Infrastructure in the North of Russia', Russian Government, 17 April 2017, government.ru/news/27387/.

36 'During the Navigation Period of 2018, Beringpromugol Plans to Export 500 Thousand Tons of Coal to the Countries of the Asia-Pacific Region', Neftegaz.ru, 23 July 2018, neftegaz.ru/news/ coal/199812-v-period-navigatsii-2018-g-beringpromugol-planiruet-eksportirovat-v-strany-aziatskotikhookeanskogo/. For an essentially positive Australian analysis of the project, see 'Tigers Realm Coal Ltd on Track at Amaam Coal Operations', Proactive, 10 July 2017, proactiveinvestors.com.au/ companies/news/180570/tigers-realm-coal-ltd-on-track-at-amaam-coal-operations-180570.html.

37 Curiously, there were no RFE representatives at a meeting Putin hosted in August 2019 of regional leaders from coal-producing regions, see 'Meeting with Leaders of Coal Mining Regions'.

38 Galina Volynets, 'Vytianuli iz medvezh'ego ugla' [Vostsibugol intends to double coal exports in 2018, using new open-pit mines], Izvestiia, 20 April 2018, interfax-russia.ru/Siberia/special. asp id $=885635 \&$ sec $=1737$ interfax-russia.ru/Siberia $/$ special .asp id $=885635 \&$ sec $=1737$. 
seen in output and export data. In 2018, output, at $6.985 \mathrm{mmt}$, was down 16.3 per cent, and exports, at $3.233 \mathrm{mmt}$, were down 27.9 per cent on $2017 .{ }^{39}$

Mechel has a new coking coalmine in the area, at El'ga. It was due to reach its Stage 1 output target of $11.7 \mathrm{mmt} / \mathrm{y}$ in 2017, yet, in 2018, managed only $4.9 \mathrm{mmt}$, of which $1.74 \mathrm{mmt}$ were exported. Those figures represented increases of 18.6 per cent and 12.4 per cent on the previous year, so at least the trend is upward. ${ }^{40}$

Other East Siberian operations are also in the early stages of development. The Apsat mine, owned by SUEK and producing coking coal, is situated about $50 \mathrm{~km}$ from the Novaia Chara station on BAM north-east of Lake Baikal. It was opened in 2012. With a planned capacity of $5 \mathrm{mmt} / \mathrm{y}$ by 2021, in 2013 it produced 652,000 metric tons, of which 462,100 metric tons were exported. ${ }^{41}$ In 2017, it produced 661,000 metric tons and, in 2018, 619,000 metric tons. ${ }^{42}$ The deposit has been described as 'difficult' and clearly there are problems getting it anywhere near planned capacity.

Elegest, in the Tuva region and owned by Ruslan Baisarov's TEPK, has a planned peak output of $15 \mathrm{mmt} / \mathrm{y}$ by 2024 , and yet, with construction of a spur line not yet begun, no coal has been mined or shipped. ${ }^{43}$

The company Kolmar, which operates in the Neriungri area of Yakutia, is interesting, not least because it is part owned by the well-connected Gennadii Timchenko-not that one would know it from descriptions of its ownership arrangements by company executives. Its current chief beneficial owner and board chair is Anna Tsivileva, the wife of Sergei Tsivilev, a founding and majority shareholder who transferred his interest when he was appointed governor of Kemerovo region. ${ }^{44}$ It has two underground operations producing coking coal. The Denisovskii mine was half finished when Kolmar took over in 2003, with plans to invest US\$450 million to expand output to $2.4 \mathrm{mmt} / \mathrm{y}$. An enrichment plant was opened in May 2018. The Inaglinskii mine is a greenfield operation, with an original

39 Tarazanov, 'Itogi raboty ugol'noi promyshlennosti', 66, 76.

40 Tarazanov, 'Itogi raboty ugol'noi promyshlennosti', 66, 76.

41 Fortescue, 'Russia's Economic Prospects in the Asia-Pacific Region', 55.

42 Tarazanov, 'Itogi raboty ugol'noi promyshlennosti', 66.

43 Volynets, 'Vytianuli iz medvezh'ego ugla'.

44 Anna Tsivileva, 'Osnovnoi benefitsiar 'Kolmar grup': kachestva nashego uglia unikal'ny' [The core beneficiary of Kolmar group: The quality of our coal is unique], Vedomosti, 1 November 2018. 
target of $6 \mathrm{mmt} / \mathrm{y}$ by 2016 and then ultimately $10.5 \mathrm{mmt} / \mathrm{y} .{ }^{45} \mathrm{In}$ practice, in 2016, the company produced across the two mines $3.7 \mathrm{mmt}$, in 2017 $4.5 \mathrm{mmt}$ and in $20184.59 \mathrm{mmt}$ (divided $2.768 \mathrm{mmt}$ and $1.821 \mathrm{mmt}$ between Denisovskii and Inaglinskii, respectively). In 2018, $1.635 \mathrm{mmt}$ were exported, an increase of 18.1 per cent on the previous year. ${ }^{46}$ In a November 2018 interview, Tsivileva set a target for exports of 60-70 per cent of output. ${ }^{47}$ She did not explain the slow progress, but made a virtue of the small scale of operations and exports, noting that the company has more flexibility in serving the needs of fussy steelmakers than Australia's bulk shippers.

Clearly, the East Siberian producers are struggling to hit their targets, as relatively modest as they are. Whether that is a sign of them being unattainable or simply a matter of more time being required is not easy to determine. On the one hand, deposits are routinely described as being difficult geologically and topographically; on the other, there have been funding and economic circumstances causing delays. The projects are owned either by smaller operators with limited access to funding or by bigger operators for whom they do not appear to be a high priority. There is no reason to believe that these circumstances will change.

If it is unlikely that Eastern Siberia and RFE will increase their share of coal exports to the APR, we must return to the implications of the continuing and, indeed, increasing reliance on Kuzbass coal.

The first-that such a circumstance reinforces the dominance of thermal coal in Russian output and exports — can be dealt with relatively quickly. The failure of coking coal to meet Program forecasts can be seen in Table 7.2, as well as the accounts of individual coking coal projects above. Coking coal prices are more than double those for thermal coal, and coking coal is likely to be more resistant to climate change-driven declines in demand. ${ }^{48} \mathrm{~A}$ coal industry so reliant on thermal coal is less profitable and resilient than one with the coking coal presence originally predicted.

45 Fortescue, 'Russia’s Economic Prospects in the Asia-Pacific Region', 55.

46 Tarazanov, 'Itogi raboty ugol'noi promyshlennosti', 68.

47 Tsivileva, 'Osnovnoi benefitsiar 'Kolmar grup'.

48 Tarazanov, 'Itogi raboty ugol'noi promyshlennosti', 75. 


\section{Transport}

The second implication of the continued reliance on Kuzbass coal-the greater distance of Kuzbass from APR markets compared to East Siberia and RFE—is a more complicated issue. There are three stages in getting Russian coal to APR markets: from mine to main transport corridor, in this case the Trans-Siberian and BAM rail lines; along those two main lines; and then through a port on the RFE coast. ${ }^{49}$

\section{Spur Lines}

Spur lines, which can run several hundred kilometres through very difficult terrain, have been the subject of endless debate and negotiation, at the core of which has been the question of whether they are infrastructure or part of the project. The government has generally taken responsibility for infrastructure, including the not insignificant cost of electricity connections and approach roads to ports. But the government (or sections of it) has baulked at paying for multibillion-rouble spur lines. Mechel went ahead and spent US\$2 billion on the $316 \mathrm{~km}$ line from its El'ga mine to Ulak on the BAM. When the company hit serious financial difficulties, the fact that it had paid for the line itself was presented as an argument by its supporters for a government bailout (which entailed half the company being sold to Gazprombank). The line remains as a limit on the capacity of the mine, and Mechel is negotiating a funding arrangement with the government to expand it, as well as considering selling out of the project altogether..$^{50}$ TEPK hung out for government money for the $410 \mathrm{~km}$, \$192.4 billion Elegest line. A concession agreement was reached in late

49 It should be noted that a significant percentage of coal is exported across a land border-72.4 of $132.5 \mathrm{mmt}$ of exports shipped by rail in 2018. See, Tarazanov, 'Itogi raboty ugol'noi promyshlennosti', 77. Most of this is presumably across European borders, although Zabaikal'sk and for some reason Port Astaf'eva are also listed as land border points (the former is on the Russian-Chinese border east of Mongolia and the latter is a port near Nakhodka). Shipments directly through Zabaikal'sk to China average around 150,000 metric tons a month (e.g. in January 2017, 168,000 metric tons, and February 2019 130,000 metric tons). See, 'Transportation through the Border Crossing Zabaikalsk in January Increased by $13.8 \%$ - up to 1.4 Million Tons', TASS, 15 February 2017, tass. ru/transport/4021986; 'FGK Transshipments on the Border with China Doubled', Logirus, 25 March 2017, logirus.ru/news/transport/peregruzki_fgk_na_granitse_s_kitaem_vyrosli_vdvoe.html.

50 Ol'ga Adamchuk, Vitalii Petlevoi, Polina Trifonova, "Mechel' ishchet sposob snizit' raskhody na zhelznuiu dorogu do El'ginskogo mestorozhdeniia' [Mechel is looking for a way to cut expenditure on the rail line to the El'ga deposit], Vedomosti, 8 October 2018; Vitalii Petlevoi, Ol'ga Adamchuk, Artur Toporkov, Polina Trifonova, 'Mechel mozhet rasstat'sia s glavnym proektom' [Mechel might say goodbye to its main project], Vedomosti, 19 February 2019; Vitalii Petlevoi, 'Gazprombank nashel pokupatelia na $49 \% \mathrm{v}$ odnom iz krupneishikh ugol'nykh proektov' [Gazprombank has found a buyer for $49 \%$ of one of the biggest coal projects], Vedomosti, 23 August 2019. 
2017, with a large part of the funding to come from bonds issued by Gasprom's assets manager 'Leader' (Lider). ${ }^{51}$ In 2020, the project entered an active planning phase with an update provided noting trains would run by $2023 . .^{52}$

\section{Ports}

At the other end of the transport chain are coal-loading ports. All the main coal exporters have, or are in the process of building, coal terminals on the RFE seaboard. In an earlier study, I noted that announced expansion plans in the middle of the current decade matched the forecast levels of exports to the APR. ${ }^{53}$ But that was when forecast exports in 2030 were $110 \mathrm{mmt} / \mathrm{y}$. The Ministry of Energy's forecast is now $207 \mathrm{mmt} / \mathrm{y}$ by 2025 . In 2018, Russian Railways estimated that, by 2026, RFE port capacity would stand at $172 \mathrm{mmt} / \mathrm{y}-50 \mathrm{mmt} / \mathrm{y}$ more than required..$^{54}$ If the Russian Ministry of Energy is more cautious than coal producers in its forecasts, Russian Railways is even more so, as it struggles to serve the needs of producers. Coal and coke exports through RFE ports increased steadily from zero in 2006 to $42 \mathrm{mmt}$ in 2011 and $82 \mathrm{mmt}$ in 2016.55 Russian Railways data show shipments through RFE ports of coal alone of $61.93 \mathrm{mmt}$ in 2015, $63.99 \mathrm{mmt}$ in 2016, $70.96 \mathrm{mmt}$ in 2017 and $73.38 \mathrm{mmt}$ in $2018 . .^{56}$

Turning to individual ports, SUEK has a terminal at Vanino, east of Khabarovsk. In 2017, it shipped around $20 \mathrm{mmt}$, with its most recent plan to ship $40 \mathrm{mmt} / \mathrm{y}$ by $2024 .{ }^{57}$ Pos'et, south of Vladivostok, is owned by Mechel. It had a capacity of $4.5 \mathrm{mmt} / \mathrm{y}$ in 2015; in 2016, it shipped

51 Natal'ia Skorlygina, 'Dobycha uglia pod garantii biudzheta' [Coal output guaranteed by the budget], Kommersant, 19 April 2018.

52 Railfreight, 'This is Russia's most ambitious railway project: Line to Siberia', 17 March 2020, www.railfreight.com/railfreight/2020/03/17/this-is-russias-most-ambitious-railway-project-line-tosiberia/.

53 Fortescue, 'Russia's Economic Prospects in the Asia-Pacific Region', 57.

54 Natal'ia Skorlygina, Dmitrii Kozlov, Anastasiia Vedeneeva, 'BAM vyezhaet na ugle' [BAM lives on coal], Kommersant, 15 August 2018.

55 Dar'ia Beloglasova, 'Dal'nevostochnye porty pochti vosstanovili gruzooborot posle krizisa' [Far Eastern ports have nearly restored throughput after the crisis], Vedomosti, 5 September 2017.

56 Igor' Gennadievich Tarazanov, 'Itogi raboty ugol'noi promyshlennosti Rossii za ianvar'-dekabr' 2016 goda' [The results of the work of the coal industry in Russia for January-December 2016], Ugol' 3 (2017): 36-50, 48, doi.org/10.18796/0041-5790-2017-3-36-50; Tarazanov, 'Itogi raboty ugol'noi promyshlennosti', 76.

57 'JSC "Daltransugol": 150 Million by Sea in 15 Years', Armur Media, 14 May 2019, amurmedia. $\mathrm{ru} / \mathrm{news} / 812204$. 
$7 \mathrm{mmt}$ and, in 2018, $9 \mathrm{mmt}$, with expansion plans to $12 \mathrm{mmt} / \mathrm{y}^{58}$ Nakhodka-Vostochnyi, owned by Kuzbassrazrezugol', shipped $22.8 \mathrm{mmt}$ in 2015 and $24.2 \mathrm{mmt}$ in $2018 .{ }^{59}$ A third terminal was built to take capacity to $39 \mathrm{mmt} / \mathrm{y}$ by $2020 .^{60}$ The Sakhalin port at Shakhtersk and Port Beringovskii in Chukotka have already been mentioned.

Coal ports under development include Kolmar's Vaninotransugol' terminal at Vanino. Construction began in June 2017, with the original plan to have a capacity of $12 \mathrm{mmt} / \mathrm{y}$ by 2019 and $24 \mathrm{mmt} / \mathrm{y}$ by $2021 .^{61}$ The latter target was later moved out to 2024, and it was only in August 2018 that tenders were called for infrastructure for the first stage. ${ }^{62}$ Construction of SDS's Sukhodol loader across the Ussuri Bay from Vladivostok began in mid-2018, with plans to operate at $20 \mathrm{mmt} / \mathrm{y}$ by 2021-22. ${ }^{63}$ Dmitrii Bosov's Vostokugol' has two port projects underway. The first, Port Vera in Primor'e region, is to have a capacity of $20 \mathrm{mmt} / \mathrm{y}$ by $2022 .{ }^{64}$ In 2019, the company was fined by the environmental protection agency for operating the incomplete terminal without measures to control coal dust. ${ }^{65}$ The other, the Sever terminal at Vostochnyi near Nakhodka, was originally begun by the conglomerate Summa, but ownership was transferred in mid-2019 after Summa's owners were arrested. The planned capacity is $20 \mathrm{mmt} / \mathrm{y}$ by $2025 .{ }^{66}$

58 'Site Map', Mechel, accessed 24 August 2020, mechel.ru/sector/logistics/poset.

59 Anastasiia Vedeneeva and Anatolii Dzhumailo, 'Na Dal'nem Vostoke zhdut ugol", Kommersant, 17 August 2016; "Vostochny Port" Increased the Volume of Coal Transshipment in 2018 by 4.3\%', Regnum, 11 January 2019, regnum.ru/news/2550586.html.

60 'The Third Stage of the Specialized Coal Production and Transfer Complex', Vostport, accessed 24 August 2020, vostport.ru/business/third-stage/.

61 "'Kolmar" Will Buy Gondola Cars for 6 Billion Rubles for the Transport "Daughter", TASS, accessed 24 August 2020, tass.ru/pmef-2018/articles/5227384.

62 'Rosmorport Is Again Looking for a Contractor for the Port Infrastructure, Where Kolmar Is Building a Coal Terminal', Y2K24, 30 August 2018, www.bairdmaritime.com/ship-world/portworld/rosmorport-wraps-up-phase-one-of-construction-at-vanino-coal-export-terminal/.

63 'Port "Sukhodol" in Primorye Will Build a Closed Terminal for Transshipment of Coal', PrimaMedia, 14 June 2018, primamedia.ru/news/703049/.

64 'Port Vera', VostokUgol, accessed 3 September 2020, vostokcoal.ru/assets/porte-vera/.

65 'Rosprirodnadzor Found Violations in the Coal Port under Construction in Podyapolsky', VL.RU. News, 4 March 2019, newsvl.ru/society/2019/03/04/178651/. Coal dust pollution at RFE loaders has become a major issue, raised even with Putin at his 2017 'Direct Line' with the public. See, Anastasiia Vedeneeva and Natal'ia Skorlygina, 'S shumom is pyl'iu' [Noise and dust], Kommersant, 6 July 2017.

66 Dmitrii Dzhumailo, “'Rostekh" nashel zamenu Kitaiu' ['Rostekh' found replacement for China], Kommersant, 30 July 2018; Anastasiia Vedeneeva, 'Plius utilizatsiia vsei strany' [Recycling the whole country], Kommersant, 19 August 2019. 
We see steadily increasing capacity at established ports. They handle primarily Kuzbass coal. Progress at new ports being built for new mines in East Siberia has been slower. The projected capacity of the three major established ports-Vanino, Pos'et and Nakhodka-Vostochnyi-is $92 \mathrm{mmt} / \mathrm{y}$. The maximum projected capacity of the startup ports-Kolmar (24 mmt), Sukhodol $(20 \mathrm{mmt})$, Vera $(20 \mathrm{mmt})$ and Sever $(20 \mathrm{mmt})$ is $84 \mathrm{mmt} / \mathrm{y}$. The two combined is $176 \mathrm{mmt}$, almost precisely the 172 identified by Russian Railways above (even if the company believes $50 \mathrm{mmt} / \mathrm{y}$ will be excess to requirements). It is, however, short of Novak's expectation that $207 \mathrm{mmt}$ will be exported to the APR by then.

\section{Trans-Siberian/BAM}

While spur lines and ports are not without their issues, most focus has been on problems with the middle link in the chain-mainline rail capacity for the long haul from Kuzbass to the RFE seaboard. As indicated in Table 7.7, it is $5,500 \mathrm{~km}$ from Kuzbass to Vanino and 6,100 km to Primor'e ports. Note that the average distance from an Australian coalmine to port is $206 \mathrm{~km}$. ${ }^{67}$

Table 7.7: Distances from coal-producing regions to Shanghai ('000 km)

\begin{tabular}{|l|c|}
\hline Route & Distance \\
\hline Newcastle-Shanghai & 9,500 \\
\hline Mezhdurechensk (Kuzbass)-Vanino & 5,500 \\
\hline Mezhdurechensk-Primor'e & 6,100 \\
\hline Neriungri-Vanino & 2,100 \\
\hline Vanino-Shanghai & 3,000 \\
\hline Primor'e-Shanghai & 2,000 \\
\hline
\end{tabular}

The expansion of mainline capacity was vigorously debated in the middle years of the decade, with the economic ministries and the RFE policy block fighting against the coalminers and Russian Railways. The economic block did not want to spend the money and expressed scepticism over projected load projections; the RFE policy block wanted the money spent on manufacturing and hi-tech development in the RFE, not a resourceoriented policy in which the RFE was no more than a transit point. Russian

67 National Energy Resources Australia (NERA), Coal Industry Competitiveness Assessment, December 2016, 17, www.nera.org.au/Publications-and-insights/Attachment?Action=Download\&Attachment_ id $=150$. 
Railways, although a supporter of expansion, was very wary about taking on commitments it could not afford. ${ }^{68}$ The coalminers won. To make sense of the expansion figures bandied about is extremely difficult, and what follows is a very simplified summary.

After considerable discussion about how much capacity should be added, a figure of $66 \mathrm{mmt} / \mathrm{y}$ was agreed upon, from a base figure of around $90 \mathrm{mmt} / \mathrm{y}$ and at a cost of $\$ 562$ billion (around US $\$ 13.5$ billion at the then exchange rate). ${ }^{69}$ Russian Railways was confident that the program could be completed on schedule in 2020, although some commentators were sceptical. ${ }^{70}$ Almost as soon as the initial expansion plan got underway there was talk of a second stage, again with extensive discussion of what the target capacity should be. It was eventually decided that a further $55 \mathrm{mmt} / \mathrm{y}$ would be added at a cost of $\$ 622$ billion (around US $\$ 10.4$ billion when the amount was announced, in October 2017). In the obscure wording of Russian Railways' long-term development plan, the money would be spent on:

Increasing the transit and carrying capacity of the shipment infrastructure of the Kuzbass, BAM and Trans-Siberian mainlines in order to achieve the forecast level of loads by 2025 , including achieving a transit capacity of BAM and the Trans-Siberian mainlines of $180 \mathrm{mt}$ by 2024 and ensuring shipments in the eastern direction of $210 \mathrm{mt}$ by $2025 .{ }^{71}$

It is not stated that these capacities are specifically for coal; however, in August 2018, Novak referred to the second expansion program as adding $180 \mathrm{mmt} / \mathrm{y}$ specifically for coal, and then declared that a further increase had been negotiated, to $210 \mathrm{mmt} / \mathrm{y}$ eastwards by 2025, of which $195 \mathrm{mmt}$ would be coal. ${ }^{72}$ Clearly, the expectation is that coal will make up a very

68 Stephen Fortescue, 'Russia's "Turn to the East": A Study in Policy Making', Post-Soviet Affairs 32, no. 5 (2016) 423-54, 436-39, doi.org/10.1080/1060586X.2015.1051750; Fortescue, 'Russia's Economic Prospects in the Asia-Pacific Region', 57-58.

69 Fortescue, 'Russia’s Economic Prospects in the Asia-Pacific Region', 57.

70 Natal'ia Skorlygina, 'Nad BAMom sgushchaiutsia uchastki' [The sections are gathering over BAM], Kommersant, 16 July 2019.

71 'Dolgosrochnaia programma razvitiia otkrytogo aktsionernogo obshchestva "Rossiiskie zhelznye dorogi" do 2025 goda' [Long-term program for the development of the limited liability company Russian railways to 2025], approved by government decree no. 466-r, 19 March 2019, Appendix 8, $10-11$.

72 'Meeting of the Commission on the Development Strategy of the Fuel and Energy Complex and Environmental Safety'. 
large proportion of the eastward movement of freight. There are claims that the figures are way short of what coalminers will need, matched by counterclaims that the coalminers' estimates are exaggerated. ${ }^{73}$

Given the importance of Kuzbass coal to APR export targets, it is not only Trans-Siberian/BAM capacity that is a restraint. The coal has to get to the mainline in the first place. For that reason, considerable attention has been paid to the capacity of the rail line from Kuzbass to the main

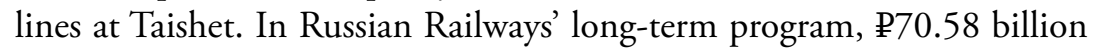
is allocated to expanding the capacity of that line (with at least $\$ 37$ billion having already been allocated).

The significance of the rail capacity issue was brought home in 2018-19, when, as prices fell in the West but remained steady in the East, miners sought to push ever more coal eastwards. Russian Railways was not able to handle the load. It issued warnings that it could offer only a 1.2 per cent increase in shipments in 2019, when the 2018 figure was down on 2017 because of delays caused by weather and trackwork. ${ }^{74}$

Promises are regularly made that the situation will improve after 2020. The commitment is there and progress is being made. But rail capacity appears likely to remain a serious restraint on expansion of coal exports to the APR, particularly as long as the major source of supply is Kuzbass. If East Siberian mines eventually contribute their hoped-for supply, that would also entail pressure on the network, albeit over shorter distances.

The issue is serious enough that alternatives have been sought. In 2018-19, Russian Railways encouraged miners to increase shipments westwards, including through offering discounts on Western routes. ${ }^{75}$ It was even suggested that the Asian price premium was such that shipping from Kuzbass through European ports and by sea to the Pacific would still be profitable. ${ }^{76}$ The mining companies were not impressed, and wanted offsetting guarantees of access eastwards. ${ }^{77}$

73 Skorlygina and Dzhumailo, 'Velikii ugol'nyi put'.

74 Natal'ia Skorlygina, 'Ugol' bol'she ne gruzit" [No more threat from coal], Kommersant, 23 January

2019; Tarazanov, 'Itogi raboty ugol'noi promyshlennosti', 76.

75 Skorlygina, 'Ugol' bol'she ne gruzit”.

76 Evgenii Zainullin, 'Ugol'shchiki snizhaiut dobychu planov' [Coal miners reduce plan output], Kommersant, 24 June 2019.

77 Natal'ia Skorlygina and Evgenii Zainullin, 'Zheleznye dorogi ishchut garanta' [Railways looking for a guarantee], Kommersant, 18 July 2019. 
A particularly imaginative approach to the Western solution has been proposed by Dmitrii Bosov-to develop coal deposits in the Taimyr region and ship them from a coal terminal at the Arctic port of Dikson. Theoretically, with the expected opening of the Northern Sea Route (NSR) for regular commercial shipping, deliveries eastwards should be possible. However, distance (Dikson is much closer to Murmansk than it is to the Pacific), to say nothing of remaining ice problems, make eastwards deliveries an unlikely commercial proposition. With a claimed output of $23 \mathrm{mmt} / \mathrm{y}$, the project is being pushed in terms of its contribution to Putin's goal of having $80 \mathrm{mmt} / \mathrm{y}$ of traffic along the NSR by $2024 .{ }^{78}$ On that basis, it has been included in the Ministry of Transport's draft plan for the NSR and dredging work commissioned. ${ }^{79}$

There are more straightforward approaches to alleviating the rail bottleneck problem. One is the Severomuissk tunnel, to the north-east of Lake Baikal. Russian Railways is clearly not enthusiastic about dealing with the bottleneck there by building a second tunnel. It claims that it would cost $\mathrm{P} 261$ billion, take 10 years to build, and could not be begun before 2025. Bosov has stepped forward to claim that he can build it for $\$ 45-51$ billion and complete it in five years. His spokesperson has said that all the preparatory work has been done and construction can start immediately to take the capacity of the tunnel from $16 \mathrm{mmt} / \mathrm{y}$ to $100 \mathrm{mmt} / \mathrm{y}$. In return for building it, Bosov wants priority access. ${ }^{80}$ In August 2019, there were reports that Russian Railways was proposing rule changes to allow priority access to customers who had invested in increasing capacity, which could well be a response to Bosov's proposal. Opposition to such a rule change is likely to be fierce. ${ }^{81}$ Experts claim the money would be better spent on more straightforward improvements to the current tunnel and other bottlenecks along the main lines. ${ }^{82}$

78 Anastasiia Vedeneeva, 'Shire Sevmorput' [Wider than the North Sea route], Kommersant, 10 April 2019.

79 'Decisions Following the Meeting on the Development of the Arctic', Russian Government, 19 December 2019, government.ru/orders/selection/401/35123/. Kuzbass coal companies are also backing a proposal to build a coal loader at Indiga on the Arctic Ocean in the Nenetsk Autonomous Region. Like Dikson, Indiga is much closer to Murmansk than the APR. See, Anatolii Dzhumailo and Anastasiia Vedeneeva, 'Pravitel'stvu podkinuli uglia' [Government left holding the coal], Kommersant, 28 November 2018.

80 Vitalii Petlevoi, Artur Toporkov and Ol'ga Adamchuk, 'Bosov prosit u Putina prioritet k BAMu i Transsibu' [Bosov asks Putin for priority access to BAM and Transsib], Vedomosti, 25 March 2019.

81 Natal'ia Skorlygina, 'Po zheleznym dorogam rasstaviat prioritety' [Priorities on the railways to be allocated], Kommersant, 2 August 2019.

82 Natal'ia Skorlygina and Anatolii Dzhumailo, 'Bilet v tonnel' okazalsia dorog' [Tunnel ticket turns out expensive], Kommersant, 26 November 2018; Natal'ia Skorlygina and Anastasiia Vedeneeva, 'Sibantratsit voobrazil sebe tonnel' [Sibantratsit dreamt up a tunnel], Kommersant, 23 April 2019. 
Another approach is to use heavier trains, with more powerful locomotives and heavier wagons. In the early debate over the Trans-Siberian/BAM expansion program, the use of more powerful locomotives came to be seen as a way of increasing capacity from the extra $66 \mathrm{mmt} / \mathrm{y}$ that work on the line itself could provide to $75 \mathrm{mmt} / \mathrm{y}$. Appropriate funding allocations have been made, although there are difficulties in obtaining locomotives even when funding is available. ${ }^{83}$

Russian Railways has long pursued a program of introducing larger wagons. The standard Russian coal wagon has an axle weight of 23.5 metric tons (the US moved some time ago to 32.4 metric tons; Australia's standard is 37.5 metric tons, with 45 metric tons wagons used on some lines). Twenty-five metric ton wagons were introduced in 2013 and in early 2018 there were 100,000 of them (of a total park of over half a million gondola wagons). There was also talk of moving to 27 metric tons wagons; however, it was recognised that that would require massive upgrades to lines and bridges, and it was decided not to proceed (beyond the short dedicated line from the Urgalugol' mine to Vanino). ${ }^{84}$ Even the 25 metric ton wagons can be received only at Nakhodka and Vanino ports. Nevertheless, in 2017 Russian Railways ran 5,800 trains over 8,000 metric tons, up from 800 in 2016. It is claimed that that added $1 \mathrm{mmt}$ to the capacity of the Trans-Siberian in that year (the 25 metric ton wagons operate only on the Trans-Siberian). ${ }^{85}$ That is hardly a gamebreaking improvement.

The Sakhalin bridge has already been mentioned. It would remove some coal—the figure $46.9 \mathrm{mmt} / \mathrm{y}$ is given — from the eastern extremities of BAM, at Selikhin station near Komsomol'sk-na-Amure. ${ }^{86}$ But this would be useful only if the proposed deepwater port were built at Il'inskoe, $430 \mathrm{~km}$ south of the bridge. A $452 \mathrm{~km}$ line from Selikhin to the bridge, and another of $127 \mathrm{~km}$ from the bridge to the existing line at Nysh would also be required. While the bridge is of no value to Sakhalin coalminers,

83 Natal'ia Skorlygina, 'BAMu povyshaet lokomotovizatsii' [More locomotivisation for BAM], Kommersant, 3 September 2019.

84 Vladimir Shtanov, 'U nas beskonechnye zapasy uglia i vysokii spros za predelami Rossii' [We have limitless coal reserves and high levels of demand beyond Russia’s borders], Vedomosti, 20 March 2018.

85 'Vagony novogo pokoleniia poddeerzhivaiut rossiiskoi eksport uglia' [New-generation wagons supporting Russia’s coal exports], Ugol'5 (2018): 94-95.

86 Natal'ia Skorlygina and Anastasiia Vedeneeva, 'Poluostrov Sakhalin' [Peninsula Sakhalin], Kommersant, 16 May 2018. 
the port would certainly improve their access to APR markets. Yet, at a cost of P253 billion for the bridge and \$540 billion for the rail lines (US $\$ 4$ and US $\$ 8.6$ billion, respectively), it appears that after a burst of interest the bridge will not be built. ${ }^{87}$

\section{Is it a Good Deal?}

Over the last five or so years, Russia has become a significant exporter of coal to the APR and, in doing so, has surpassed even its own expectations. That has encouraged it to set more ambitious targets for the future. Setting aside demand issues, whether those targets will be met depends, on the output side, on whether Kuzbass coal output will continue to grow to make up for shortfalls in forecast supply from new mines in East Siberia and the RFE, assuming those shortfalls are more than temporary startup problems. On the delivery side, questions remain about whether the rail network and ports can cope. Kuzbass coal is like West Siberian oil—one heeds predictions of its imminent demise at one's peril. Ports can probably be expanded as needed; the rail network issues appear less susceptible to blind optimism.

Nevertheless, we can expect significant and increasing amounts of coal to pass through RFE ports. Is it a good deal for Russia? Will the industry make a profit? Will the state get a return on its investment?

The coal industry is totally private, and its private owners are prepared to invest. It is claimed that, from 2010 to 2016 , \$550 billion was invested, $70-80$ per cent of which was their own funds, with the expectation

87 Andrei Zlobin, 'Stroika i geopolitika. Most na Sakhalin oboidetsia v 3,5 raza dorozhe Krymskogo' [Construction and geopolitics. The bridge to Sakhalin will cost 3.5 times more than the Crimean one], Forbes.ru, 16 May 2018, forbes.ru/biznes/361475-stroyka-i-geopolitika-most-nasahalin-oboydetsya-v-35-raza-dorozhe-krymskogo. Brief mention is made here of another outlet for Russian coal to the APR, through North Korea. There is a rail line from Khasan on the Russian side of the border to the North Korean port of Rason. At the end of 2013 it was rebuilt at a cost of US\$250 million. Depending on the political/diplomatic situation, including the willingness of the Chinese to take coal from North Korea, small shipments are carried on the line-2.5 mmt in 2017. The Russian supplier of that coal has not been identified, but it is said that the unprofitable shipment was made because of pressure from above. See, Natal'ia Skorlygina and Anatolii Dzhumailo, 'Kitai otkryl dorogu ugliu iz Rossii' [China has opened a road for coal from Russia], Kommersant, 6 September 2018. 
that they would need to spend two to three times more in the future. ${ }^{88}$ Novak said in August 2018 that $\$ 1$ trillion of private investment would be needed to reach output of $560 \mathrm{mmt} / \mathrm{y} .{ }^{89}$ The coal companies were expected to provide the great bulk of the investment in the 2030 Program, P5,014.57 billion, with the federal budget providing $\mathrm{P} 281.81$ billion (US $\$ 133$ billion and US $\$ 7.5$ billion at the mid-2014 exchange rate). The willingness to invest such sums of private capital represents a serious vote of confidence in the APR export strategy, although it is noteworthy that there is very little investment from outside, including from China and the rest of the APR.

While the sector shows dynamism and ambition, there are signs of stress. Sibuglemet went bankrupt and is being managed by the state investment bank VEB. ${ }^{90}$ Mechel very nearly followed, with Gazprombank taking half the company's shares in return for restructuring its debts. The company still struggles. ${ }^{91}$ There are high levels of indebtedness throughout the sector, ${ }^{92}$ and the most dynamic people in the industry, such as Dmitrii Bosov, come across more as adventurers than the builders of businesses. ${ }^{93}$

While government budgetary funding is low compared to the level of private investment, the pressure for increased infrastructure spending is relentless, with spur lines increasingly being accepted as an infrastructure cost for which the state will accept responsibility. One strongly suspects that the bulk of the companies' indebtedness is to state banks, although Mechel's experience reminds us that, while ultimately soft, the loans are not without cost. As a more direct cost to the state, the companies are increasingly offered significant tax concessions, with RFE ports and East Siberian and RFE mines being included in 'Vladivostok free port' and Territories for Accelerated Development (the latter were originally

88 O. I. Glinina, 'Ugol'naia promyshlennost' v Rossii: 295 let istorii i vozmozhnosti' [The coal industry in Russia: 295 years of history and new opportunities], Ugol' 10 (2017): 4-10, 6, doi.org/ 10.18796/0041-5790-2017-10-4-10.

89 'Meeting of the Commission on the Development Strategy of the Fuel and Energy Complex and Environmental Safety'.

90 'Bankruptcy Is Not Death Forever, it's Just a Change of Ownership', 1Prime.Ru, 14 June 2019, 1prime.ru/finance/20190614/830071557.html.

91 Petlevoi, 'Gazprombank nashel pokupatelia na $49 \%$ '.

92 'On the State and Prospects of Development of the Coal Industry', Russian Government, 4 April 2016, government.ru/news/22437/, see comments by Sokolov.

93 On Bosov's debts and the lack of profitability of his company, Petlevoi, Toporkov and Adamchuk, 'Bosov prosit u Putina prioritet k BAMu i Transsibu'. 
devised explicitly to encourage investment in non-resource projects).${ }^{94}$ In August 2019, there were calls for cuts in the resources tax, despite coal companies' resources tax payments already being very small. ${ }^{95}$

Costs are high because of the standard Russian factors of climate, distance and geology. Russian coal deposits are almost invariably described as 'difficult' and high levels of enrichment are required. ${ }^{96}$ Ice acts as a constraint on both mining and transport. Rail wagons and ports have to be equipped to handle frozen coal: in January 2018, all shipments of coal were halted when it was too cold to dig and transport it. ${ }^{97}$ Topographically, roads and railway lines have to be laid and power delivered in extremely challenging terrain. But, above all, coal has to be shipped, usually by rail, over extremely long distances. This applies particularly to coal coming from Kuzbass to APR destinations.

Costs are high both for capital investment and operations. The TransSiberian/BAM upgrade is more expensive than Russian Railways projects in other parts of the country; the second stage-in nominal terms at least-is more expensive than the first and, arguably, it is all less costeffective than equivalent infrastructure expansions elsewhere. ${ }^{98}$ The El'ga and Elegest spur lines, at around US $\$ 2$ and US $\$ 3.3$ billion for 316 and $410 \mathrm{~km}$, respectively, are more expensive than the $388 \mathrm{~km}$ rail line originally planned for the controversial Adani mine in Queensland at A $\$ 2.3$ billion. ${ }^{99}$

By their nature, the benefits of infrastructure investment can be slow in coming. The Australian coal sector experienced a big surge in transport costs because of high capital expenditure, peaking in 2012, followed by a steady decline at a time when output was rising. ${ }^{100}$ Russia might

94 'On Decisions Following the Meeting on the State and Prospects of Development of the Coal Industry', Russian Government, 12 April 2016, government.ru/orders/22567/. See also Fortescue, 'Russia's “Turn to the East": A Study in Policy Making'.

95 Evgenii Zainullin, 'Ugliu mogut snizit' nalogi' [They might reduce taxes for coal], Kommersant, 26 August 2019.

96 For levels of enrichment, see Tarazanov, 'Itogi raboty ugol'noi promyshlennosti', 71.

97 'Coal Did Not Go: Its Loading on the Railways Falls for the First Time in a Year and a Half', Kommersant, 2 February 2018, kommersant.ru/doc/3536013.

98 Fortescue, 'Russia’s “Turn to the East”: A Study in Policy Making', Table 1.

99 Samantha Hepburn, 'Adani's New Mini Version of its Mega Mine Still Faces Some Big Hurdles', Conversation, 3 December 2018, theconversation.com/adanis-new-mini-version-of-its-mega-minestill-faces-some-big-hurdles-108038. As Tsivileva notes, greenfield Australian projects-Adani for example_-are further inland, eroding the Australian transport cost advantage, but the rail distances are still nothing like Russia's. See, Tsivileva, 'Osnovnoi benefitsiar 'Kolmar grup'.

100 NERA, Coal Industry Competitiveness Assessment, Figure 16. 
experience the same, although land distances are always going to be great and so operational transport costs will always be high. This is even when freight rates are no better than break-even for Russian Railways and considerably lower than for other bulk shippers. ${ }^{101}$ One notes that in 2018 Evraz's costs went up 23.2 per cent, because it increased the share of its output that went to exports, even when the biggest increase was in relatively cheap shipments to Europe. ${ }^{102}$ This suggests that the export price premium has to be considerable for transport costs not to erode profitability.

\section{A National Energy Resources Australia (NERA) report compared} Australian coal competitiveness with that of nine peers, of which Russia was one. ${ }^{103}$ Competitiveness was measured for four stages: exploration and development, extraction and production, transportation, and closure and rehabilitation. Overall, Russia ranked fifth, behind China, South Africa, Australia and the United States. Unfortunately, the report revealed Russia's score for only one stage-extraction and productionfor which it ranked number one (Russia 6.7, average 5.3, Australia 5). That Australia did poorly in that category is not surprising; that Russia did so well is somewhat so. The data underlying the NERA rankings are not provided or accessible. We know that Russian labour costs are low, but so is productivity-according to Voskoboinik and Rozhkov, five to nine times below that of developed countries, including 3.9 times below Australia. ${ }^{104}$ Reductions in labour force appear to be at an end and wages keep rising. ${ }^{105}$ One would also expect the climate, location and geology issues already described to negatively affect production competitiveness. ${ }^{106}$ Russia's transportation score is not provided, but one would expect it to be in that area that it loses any advantages it might have in extraction and production.

101 Farid Khusainov, 'Tarifnye uspekhi ugol'shchikov' [Coalminers' freight rate successes], Vedomosti, 16 October 2018.

102 Evraz, Annual Report \& Accounts, 2018, 59-60, www.evraz.com/en/investors/reports-and-results/ annual-reports/.

103 NERA, Coal Industry Competitiveness Assessment.

104 Mikhail Voskoboinikov and Anatolii Rozhkov, 'Retrospektivnaia i prognoznaia otsenki effektivnosti tekhnoligicheskogo razvitiia ugol'noi promyshlennosti Rossii' [Retrospective and predictive measures of the efficiency of the technological development of the Russian coal industry], Ugol'2 (2018): 48-53, 48. 105 Tarazanov, 'Itogi raboty ugol'noi promyshlennosti', 71.

106 Tsivileva, while noting that topographically Russia is very difficult and that their operations are closed one month a year because of the cold, considers that Russia has an advantage over Australia in that the climate is stable compared to Australia's cyclones, floods, etc. She also believes that Russia's reputation for poor reliability is undeserved and at least partly the result of Australian propaganda. See, Tsivileva, 'Osnovnoi benefitsiar 'Kolmar grup'. 
Australia, even with some weaknesses in competitiveness, has traditionally been able to cover for low margins when prices are low by ramping up volume. That option is not available to Russia, or certainly not on the same scale as Australia. To the extent that it is able to do so, it is with volume from Kuzbass. Kuzbass coal has a transport competitive disadvantage and is lower-margin thermal coal. While Russia has a significant domestic market to fall back on, it is not big enough to cover any significant drop-off in exports.

To conclude that Russia's APR export strategy is a risky one is not to deny that the revival of the Russian coal industry and the move into APR markets have been impressive. While falling demand and prices could leave producers with large unserviceable debts and the state with underutilised infrastructure, the state would likely subsidise producers more heavily — a threatening situation for Russia's budget and its competitors. 
This text is taken from Russian Energy Strategy in the Asia-Pacific: Implications for Australia, edited by Elizabeth Buchanan, published 2021 by ANU Press, The Australian National University, Canberra, Australia.

doi.org/10.22459/RESAP.2021.07 